\title{
SELECTED ASPECTS OF THE SECURITY OF THE PROCESS DATA TRANSMISSION IN THE DISTRIBUTED CONTROL SYSTEM
}

\author{
WYBRANE ASPEKTY BEZPIECZEŃSTWA \\ PRZESYLANIA DANYCH PROCESOWYCH \\ W ROZPROSZONYM SYSTEMIE STEROWANIA
}

\author{
Marcin Bednarek ${ }^{1}$, Tadeusz Dąbrowski ${ }^{2}$, Tomasz Wawer ${ }^{3}$ \\ ${ }^{1}$ Rzeszow University of Technology \\ ${ }^{2}$ Military University of Technology \\ ${ }^{3}$ Wawer i Synowie, Warszawa
}

bednarek@prz.edu.pl; tadeusz.dabrowski@wat.edu.pl; wawer.tomasz@gmail.com

\begin{abstract}
Communication between the process stations of the distributed control system is carried out. By the supervision and therapeutic systems of the stations communication process diagnosis is performed. Supervision and therapeutic systems are responsible for the security of transmitted data. The security is considered in this article mainly in the aspect of resistance to external destructive factors on the data transmission process. It is assumed that the transmission security can be provided by mechanisms protecting the integrity of the transmitted data. Correctness of the data is controlled by using one-way hash function calculated on the basis of the transmitted value variable and also is attached to the transmitted data. This allows to maintain the integrity of the transmitted process data. A solutions using one-way hash function to protection of the transmission before changing message contents (caused by eg. intruder interference) are proposed in the article.
\end{abstract}

Keywords: : transmission security, integrity, distributed control system

Streszczenie: Pomiędzy stacjami procesowymi rozproszonego systemu sterowania prowadzona jest komunikacja. Układy dozorujaco-terapeutyczne stacji systemu realizuja diagnozowanie procesu komunikacji $i$ odpowiadaja za bezpieczeństwo przesylanych danych. Bezpieczeństwo to jest rozpatrywane $w$ niniejszym artykule głównie $w$ aspekcie odporności na działanie zewnętrznych czynników destrukcyjnych na proces transmisji danych. Przyjmuje sie przy tym, że bezpieczeństwo transmisji może być zapewnione za pomoca mechanizmów chroniacych integralność przesytanych danych. Poprawność danych kontrolowana jest za pomoca wykorzystania jednokierunkowej funkcji skrótu obliczanej z wartości przesytanej zmiennej $i$ dodatkowo dotaczanej do transmitowanych danych. $W$ artykule proponuje się rozwiazania wykorzystania jednokierunkowej funkcji skrótu do zabezpieczenia transmisji przed zmiana jej treści spowodowana np. ingerencją intruza.

Stowa kluczowe: bezpieczeństwo transmisji, integralność, rozproszony system sterowania 
Selected aspects of the security of the process data transmission in the distributed... Wybrane aspekty bezpieczeństwa przesyłania danych procesowych...

\section{SELECTED ASPECTS OF THE SECURITY OF THE PROCESS DATA TRANSMISSION IN THE DISTRIBUTED CONTROL SYSTEM}

\section{Introduction}

A distributed control system $(D C S)$ can be divided into several types of devices communicating with each other. These are process stations - responsible for the process control (PS - Process Station), operator stations - provide visualization process and enable interaction with an operator (OS - Operator Station). A fragment of such a mini-DCS is shown in Figure 1.

The configuration of the station (PS1, PS2 and OS) is generally carried out by means of the engineering station (ES - Engineering Station), which is also a diagnostic tool [6]. Projects created in the engineering station, including the configuration of the station and control programs, are transmitted via a computer network to processing stations. The same configuration is sent to the operator station to visualize the process [7].

The stations of this system communicate. The processing of local stations depends on correct process variables obtained from remote stations. Stations of the system exchange data - process variables.

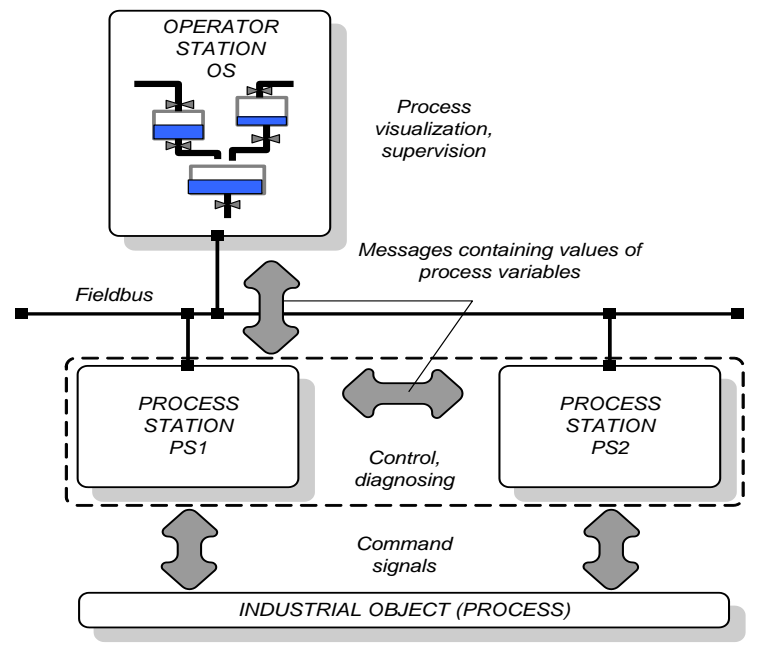

Fig. 1. Transmission of the process variables in a mini distributed system

Supervision and therapeutic system of the stations run diagnostics of the communication process. Their task is to control the communication in such a way as to ensure the security of the transmitted data. The security of transmitted data can be seen in two aspects [1.10]. In the first, in terms of sensitivity to external destructive factors, the process of data transmission, and thus the effects of these factors affect the security of the process control system. Security of transmission can be achieved by means of mechanisms to ensure the integrity of the transmitted data. In the second - to secure the transmitted data against unauthorized access from the outside. 
Remaining of communication system in the state of security - a symptom of what is ability to deliver the correct process variables from one station to another within a given period of time - is, for the purposes of this study, identified with the remaining communication system in the state of task fitness. Accuracy is controlled by a one-way hash function [14] calculated from the value of the transmitted variable and additionally is attached to the transmitted data. This results in preservation of the integrity of data process. The study proposes the use of one-way hash function to protect transmission before the change of its content due to eg. the intruder interference [10]. Presented solutions are using one or more transmission channels.

\section{Fitness of the system}

The fitness of a data transmission system is considered in aspect of intervals. According to the assumptions contained in the potential-effect module approach to diagnosing human-engineering systems [5] it can be assumed that the communication system is considered fit to perform the task of usage only if the disposed potential between the time the task is no less than the potential required in this interval. In the present case, this means the need to ensure the transmission time is not longer than the imposed time task. This can be written as follows (1):

where:

$$
\left.\begin{array}{l}
F_{P-d y s}\left(T_{t r}\right) \geq F_{P-w y m}\left(T_{z a d}\right) \\
T_{t r} \leq T_{z a d}
\end{array}\right\} \Rightarrow \varepsilon=\varepsilon^{l}
$$

$$
\begin{array}{ll}
F_{P-d y s} & \text { - disposed potential; } \\
F_{P-w y m} \text { - required potential; } \\
T_{t r} \quad \text { - transmission time; } \\
T_{z a d} \text { - time task; } \\
\varepsilon \quad \text { - state of the transmission system; } \\
\varepsilon^{l} \quad \text { - state of fitness of the transmission system. }
\end{array}
$$

Security disposed potential, and more specifically the level of the disposed potential, can be expressed as a number of type mappings, which correctly and accurately transmitted the message components (the levels of the security required potential can be determined by analogy):

$F_{P-d y s}=1$ - providing an explicit (plaintext) value of the process variable;

$F_{P-d y s}=2$ - providing an explicit value of the process variable with attached, the calculated hash value of the process variable;

$F_{P-d y s}=3$ - providing encrypted value of the process variable with attached, the calculated hash value of the process variable;

$F_{P-d y s}=4$ - providing encrypted value of the process variable with attached, the calculated, encrypted of the process variable. 
Selected aspects of the security of the process data transmission in the distributed... Wybrane aspekty bezpieczeństwa przesyłania danych procesowych...

The second condition of fitness (and hence security) of transmission system is not exceeding the allowable transmission time interval of the task (1). Time task can be expressed through a cycle time of message transmission. The transmission is in fact carried out periodically at regular intervals:

where:

$$
T_{z a d}=T_{C}
$$

$T_{C}-$ message cycle time.

Substituting (1) with (2) condition (3) is obtained:

$$
T_{t r} \leq T_{C}
$$

Thus, the transmission time of a message containing the value of the variable and the information needed to verify the integrity of data transferred (hash value), and the possible return confirmation shall not be greater than the cycle time of sending the message (it is a prerequisite to an state of fitness condition). It should be noted that the transmission time also includes the time needed for data preparation for transfer. Thereafter, we are discussed aspects of the transmission time, and methods to increase the time redundancy allowing for example possible repetition of messages.

\section{Standard transmission}

The standard transmission, without any additional software safeguards of the integrity of the message is carried out as shown in Figure 2. Process station (transmitter) sends a message containing the value of the recipient process station $\left(F_{P-d y s}=1\right)$. If the confirmation is required of value reception - message is returned back. A positive result of checking compliance with the received message sent and not to exceed the duration of the task proves the fitness of the system (according to the standard accepted levels: $\left.F_{P-w y m}=1\right)$.

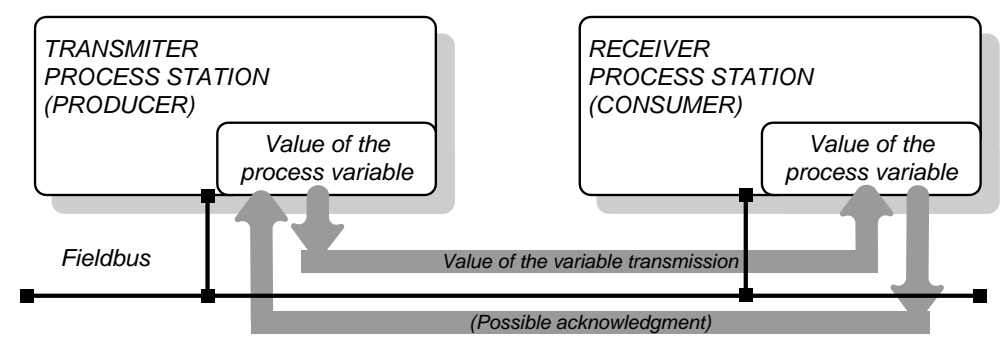

Fig. 2. Standard transmission of the process variables

Figure 3 shows schematically the components of a transmission time for a case without acknowledgement (a) and with acknowledgement (b). 
a)

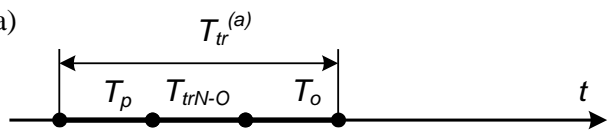

b)

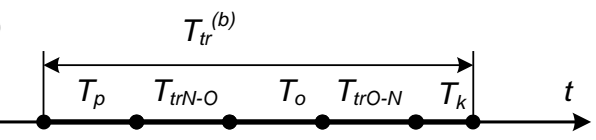

Fig. 3. Transmission time of the variable value:

a) without acknowledgement; $b$ ) with acknowledgement

For the case without confirmation (Fig. 3a) transmission time, which for security purposes (and thus an state of fitness) of communication system, can not exceed the cycle time, is (4):

$$
T_{t r}^{(a)}=T_{p}+T_{t r N-O}+T_{o}
$$

where:

$T_{p} \quad$ - the time required to prepare a variable value by the sender;

$T_{t r N-O}$ - message transmission time (containing the variable) from the transmitter to the receiver;

$T_{o} \quad$ - the time required to prepare variable value for processing by the receiver.

In the case of the version with acknowledgement (Fig. 3b) the total transmission time does not include time periods associated with the return transmission of data and comparing the value returned with the sent value (5):

$$
T_{t r}^{(b)}=T_{p}+T_{t r N-O}+T_{o}+T_{t r O-N}+T_{k}
$$

where:

$T_{\text {tro-N }}$ - the time return message transmission (including the value of the variable) from the recipient to the sender;

$T_{k} \quad$ - the time required for comparison of the return value with the value from sender.

When calculating the cycle time, according to which regular messages are sent, be sure to provide adequate time redundancy (reserve time) $\Delta t$ :

$$
\Delta t=T_{c}-T_{t r} \geq 0
$$

minimally:

$$
T_{c}=T_{t r}
$$


Selected aspects of the security of the process data transmission in the distributed... Wybrane aspekty bezpieczeństwa przesyłania danych procesowych...

In the case of the use of one-way hash function to increase the security of transmitted data follow the instructions in section 4.

\section{Ensuring the integrity of the transmitted data}

In order to ensure greater security in the system, procedure can be used to join additional value of calculated hash to the process variable, This type of "treatment", the disposed potential obtained by the correct transmission of the message is increased (as section 2) to the $F_{P-d y s}=2$.

In this variant, the transmission sender (transmitter, Fig. 4) calculates the hash value of the transferred variable. Concatenated values are sent in a joint message to the recipient (receiver, consumer). The recipient extracts from the message; value of the variable and the value of the hash function. Recalculates a hash value and compares it with the value received. If the result obtained confirmation of noninfringement of the process variable and does not exceed the set up cycle time (transmission time $T_{t r}{ }^{(c)}$ ), shall be deemed to transmission system for fit despite the increased level of required potential $\left(F_{p \text {-wym-max }}=2\right)$.

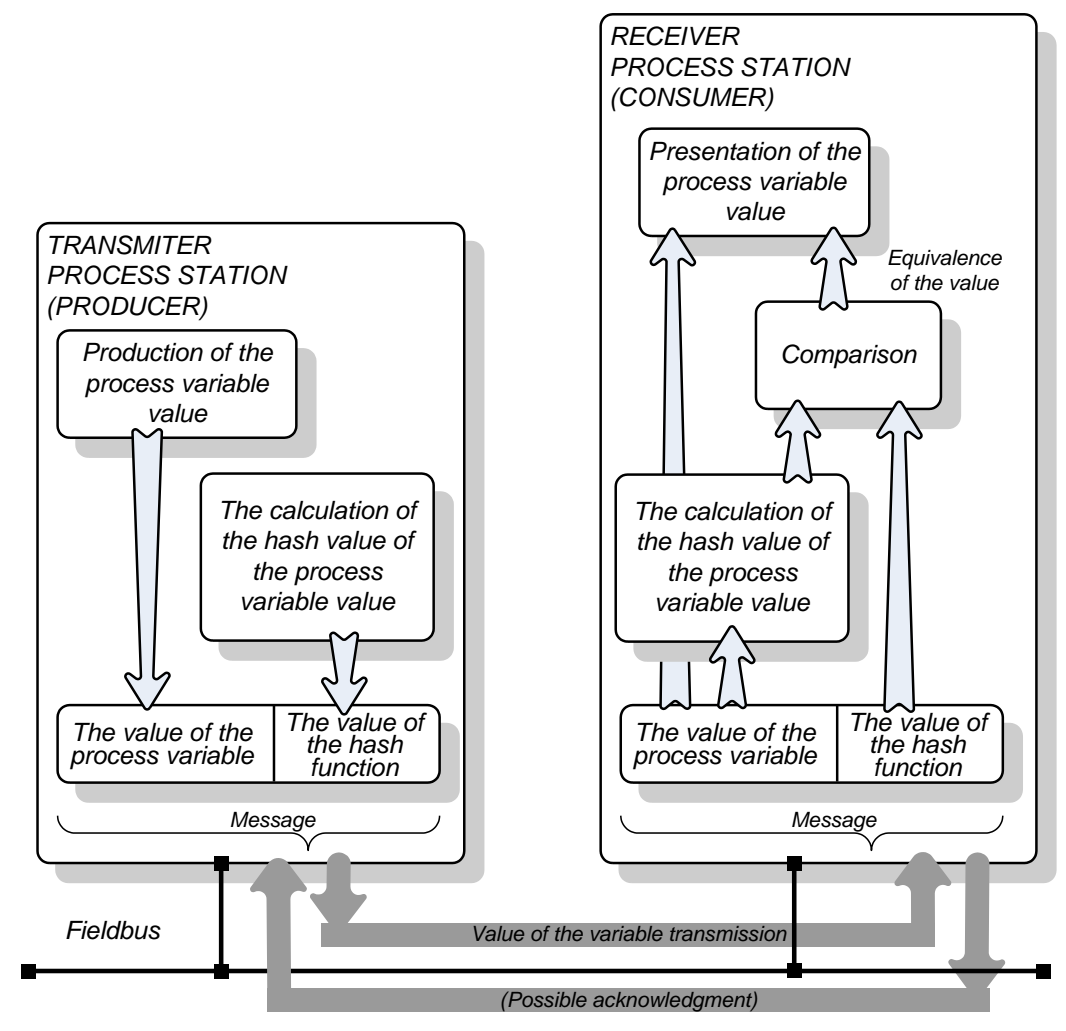

Fig. 4. Transmission of the process variable with attached hash value 
Times: preparation, transmission and reception are increased accordingly by the time necessary to process the hash values (Fig. 5a - without acknowledgement):

- preparation time value for sending by the sender:

$$
T_{p}=T_{p d}+T_{p s}
$$

where:

$T_{p d}$ - the time required to prepare variable;

$T_{p s}$ - the time required to prepare the hash value of the variable value.

- the data transmission time from the sender to the receiver:

$$
T_{t r N-O}=T_{t r d}+T_{t r s}
$$

where:

$T_{\text {trd }}$ - the time to transfer variable value;

$T_{t r s}$ - the time required for the production the hash value from the received variable value;

- time required to prepare value for the further processing by the receiver:

where:

$$
T_{o}=T_{o d}+T_{o s}+T_{o k s}
$$

$T_{o d}$ - the time required to receive variable value by the recipient;

$T_{o s} \quad$ - the time required for receiving the hash value of the variable and for calculating its own hash value;

$T_{o k s}$ - the time required to comparison the received hash and computed by the recipient.

Substituting (8-10) to (4) the components of the total transmission time in the variant of the calculation of hash values without acknowledgement (11):

$$
T_{t r}^{(c)}=T_{p}+T_{t r N-O}+T_{o}=T_{p d}+T_{p s}+T_{t r d}+T_{t r s}+T_{o d}+T_{o s}+T_{o k s}
$$

a)

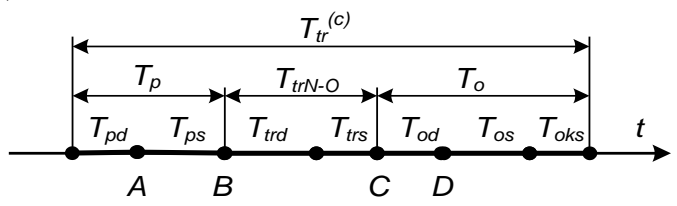

b)

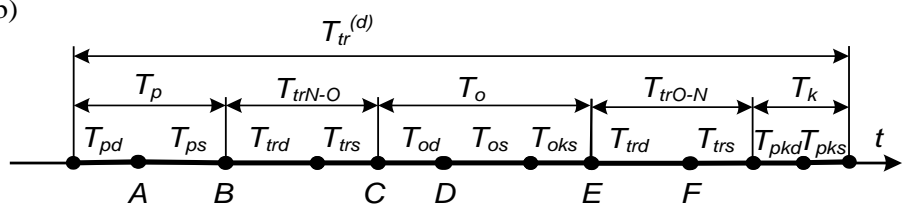

Fig. 5. Transmission time of the variable value with attached hash value:

a) without acknowledgement; $b$ ) with acknowledgement 
Selected aspects of the security of the process data transmission in the distributed... Wybrane aspekty bezpieczeństwa przesyłania danych procesowych...

In the case of the variant with acknowledgment of receipt (i.e. session support service) to the sum of the times according to (5), there are also additional components (12), i.e. .:

$$
\begin{gathered}
T_{t r}^{(d)}=T_{p}+T_{t r N-O}+T_{o}= \\
=T_{p d}+T_{p s}+T_{t r d}+T_{t r s}+T_{o d}+T_{o s}+T_{o k s}+T_{t r d}+T_{t r s}+T_{o d}+T_{p k d}+T_{p k s}= \\
=T_{p d}+T_{p s}+2 T_{t r d}+2 T_{t r s}+T_{o d}+T_{o s}+T_{o k s}+T_{o d}+T_{p k d}+T_{p k s}
\end{gathered}
$$

where:

$T_{\text {trd }}$ - time of the additional reverse variable value transmission;

$T_{\text {trs }}$ - time of the additional reverse hash value transmission;

$T_{p k d}$ - the time required for comparison returned value variable with a sent value;

$T_{p k s}$ - the time required for comparison returned variable value with a sent value.

Additional value of time slots for the fitness of the transmission system may not result in failure condition (3). In practice, this can be achieved in two ways:

1) temporarily alleviation of the time condition, i.e. increasing the cycle time at lub which the message with values is generated

2) using separate transmission process variable and hash value using a separate transmission channel for each of them.

Both methods increase the available time redundancy (see (6)).

In accordance with the above 2 a way to increase the reserves of the time necessary for the proper and safe operation of the transmission system is the division of transmission into two messages, each carrying information about one of the two values - for a separate variable, separate the hash value - transmitted separate transmission channels. With this organization, the process of transmission yields reduced time transmission of all information.

In the case of application of the above method, variable transmission can begin even if the value of the hash function is not yet ready for sending (Fig. 5, point $A$ ). This gives time savings in $A B$. Time gain can be obtained also in the process of collection and processing. Processing of hash values can also start earlier than in case of a serial construction of a transmission system (Fig. 5, point $C$ ). Saving time determines the $C D$. Similarly, in case of the acknowledgement - increase in time redundancy $(E F)$ is achieved by earlier return transmission of hash values (Fig. 5b, point $E$ ). 
Tomasz Wawer

\section{The tests of the execution time of the block providing the integrity of the transmitted data}

In order to compare and illustrate the scale of transmission time increase, using a block that calculates the value of hash function according to the algorithm SHA256 [9], made in ST programming language [11], results are given for industrial controller emulator running in a virtual environment. Virtual system has $2 \mathrm{~GB}$ of RAM, uses a laptop computer with a processor IntelCore2 Duo $2.0 \mathrm{GHz}$. The cycle time of user task of the process station calculating the hash value is set at $5 \mathrm{~ms}$ [2]. In the drawings 6 and 7 show the results of a series of seven tests measure the time of calculating the hash value from the input value 20 and 200. The time values obtained in both cases are in the range from 38 to $68 \mathrm{~ms}$.

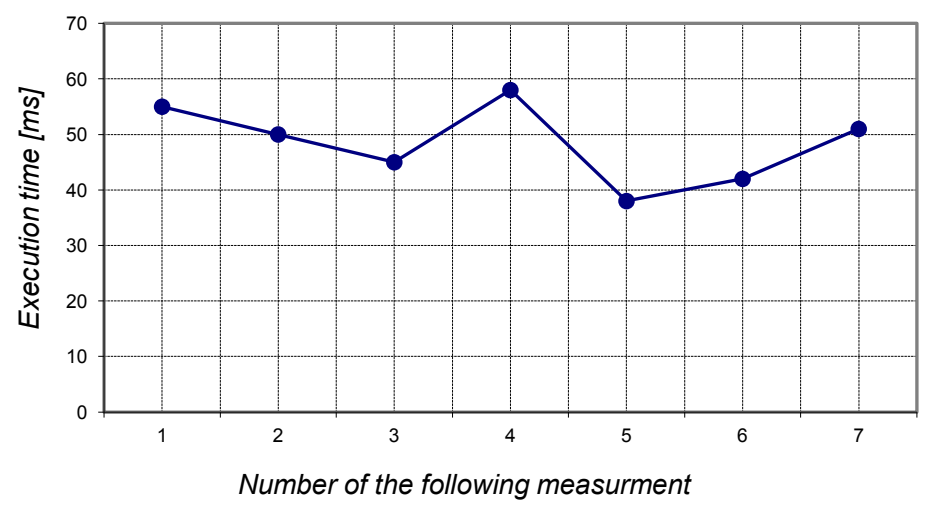

Fig. 6. Execution time for the block calculating hash function SHA-256 for task cycle time of $5 \mathrm{~ms}$ and input value of 20

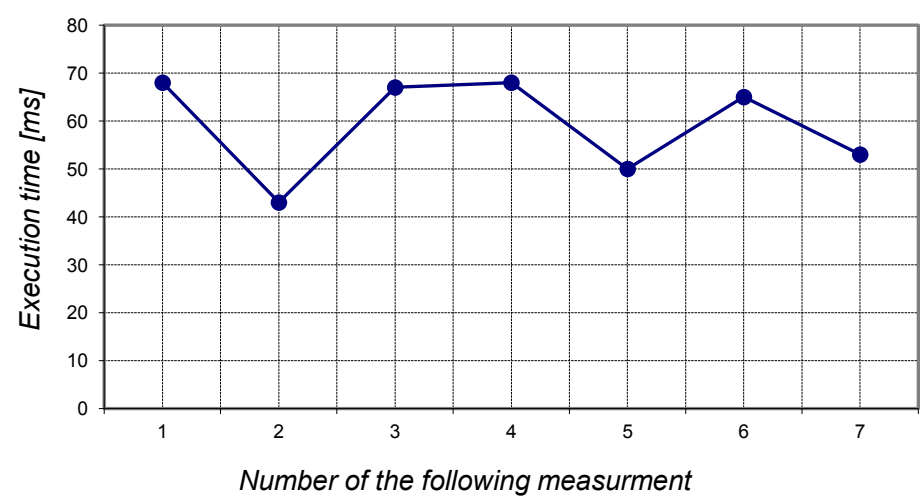

Fig. 7. Execution time for the block calculating hash function SHA-256 for task cycle time of $5 \mathrm{~ms}$ and input value of 200 
Selected aspects of the security of the process data transmission in the distributed... Wybrane aspekty bezpieczeństwa przesyłania danych procesowych...

The obtained times of the block hash calculation values give a more complete picture only after comparing them with the set up cycle time with which the message is sent. It can be seen that for the assumed cycle time of 200ms message exchange, these values are, respectively, from $19 \%$ to $34 \%$ of the total time available for a data exchange. It is not a problem for the timing matched that way . In more complex applications, where the value of the hash function is calculated repeatedly and there are other security mechanisms e.g. encryption additionally applied, selection of too low user task time $T_{\text {zad }}$ can lead to unfitness of transmission system.

\section{Summary}

On the basis of the discussion in this paper can make some propositions for communication using security mechanisms:

1) Application of appended hash value, calculated on the basis of the transmitted process variable allows to preserve the integrity of the message and prevents potential attacks on the integrity.

2) The use of the above mechanism allows an increase of disposed security potential of the communication system.

3) The repeated use of hash function increases the time necessary to obtain the reception of the process variable. This fact should be taken into account when designing cyclical exchanges. The length of the cycle time should be extended to avoid unfitness of the system caused by exceeding the required transmission time.

4) The time required to calculate the hash value is relatively small in relation to possible repetition of failed, unfitness messages (tens of milliseconds calculations in relation to e.g. a few seconds settable parameter timeout).

\section{References}

[1] Anderson Ross J.: Security Engineering: A Guide to Building Dependable Distributed Systems, 2nd Edition, Willey, Hoboken 2008.

[2] Bednarek M.: Wizualizacja procesów. Laboratorium, Oficyna Wydawnicza Politechniki Rzeszowskiej, Rzeszów 2004.

[3] Bednarek M., Dąbrowski T.: Koncepcja zabezpieczenia transmisji danych w mobilnym systemie diagnostycznym, Journal of KONBiN, z.2(26)/2013, s. 61-70.

[4] Bednarek M., Dąbrowski T., Wiśnios M.: Koncepcja zabezpieczenia transmisji pomiędzy stacjami diagnostycznymi, Pomiary Automatyka Kontrola, Wydawnictwo PAK, nr 9/2014, 749-752.

[5] Dąbrowski T.: Diagnozowanie systemów antropotechnicznych w ujęciu potencjałowo-efektowym, Rozpr. hab., Wyd. Wojskowej Akademii Technicznej, Warszawa 2001.

[6] AC800F. Engineering Manual. IEC 61131-3 Programming.

[7] Technical Documentation Control Builder F. Freelance Getting Started, 2010. 
[8] Ferguson N., Schneier B., Kohno T.: Cryptography Engineering: Design Principles and Practical Applications, Willey, 2010.

[9] Gilbert Henri, Handschuh Helena: Security Analysis of SHA-256 and Sisters, Selected Areas in Cryptography, Springer 2003, s. 175-193.

[10] Liderman K.: Bezpieczeństwo informacyjne. Wydawnictwo PWN, Warszawa 2012.

[11] IEC 61131-3:2013. Programmable controllers - Part 3: Programming languages.

[12] Stallings W.: Kryptografia i bezpieczeństwo sieci komputerowych. Matematyka szyfrów i techniki kryptologii, Helion, 2011.

[13] Stamp M.: Information security, J. Wiley \& Sons, Hoboken, 2006.

[14] Stinson R. Douglas: Kryptografia. W teorii i praktyce, WNT, Warszawa 2005.

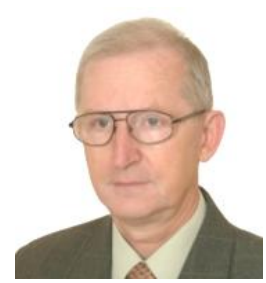

Tadeusz Dabrowski, Assoc. Prof. PhD, Eng. He works for Institute of Electronic Systems, Faculty of Electronics Military University of Technology. Specialisation: operating theory, especially technical diagnostics of men-machine systems. He is the author/co-author of over 150 publications. (Share: 30\%).

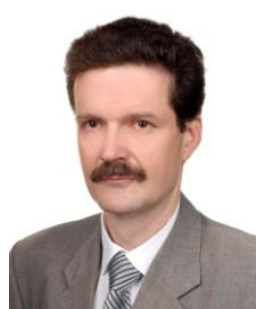

Marcin Bednarek, PhD. Eng. works as an assistant professor in the Department of Computer and Control Engineering the Faculty of Electrical and Computer Engineering Rzeszow University of Technology. The main area of his scientific interests includes diagnostics of the human-engineering systems, communication in distributed control systems, reliability and security of the systems. He is the author/co-author of over 100 publications. (Share: $50 \%$ ).

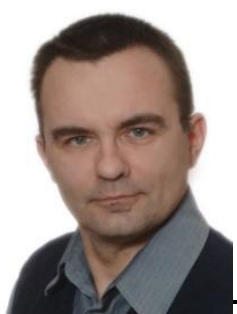

Tomasz Wawer M.Sc. Eng. graduated at Warsaw Technical University, Mechatronics. He is server and storage design and implementation specialist. He has been developing his own IT consulting company for 5 years. He is a radioamateur, callsign SQ5RIX. (Share: 20\%). 
Selected aspects of the security of the process data transmission in the distributed... Wybrane aspekty bezpieczeństwa przesytania danych procesowych...

\section{WYBRANE ASPEKTY BEZPIECZEŃSTWA PRZESYLANIA DANYCH PROCESOWYCH W ROZPROSZONYM SYSTEMIE STEROWANIA}

\section{Wprowadzenie}

W rozproszonym systemie sterowania można wyróżnić kilka rodzajów urządzeń komunikujących się wzajemnie. Są nimi stacje procesowe - odpowiedzialne za sterowanie procesem (PS - ang. Process Station), stacje operatorskie - prowadzące wizualizację procesu oraz umożliwiające oddziaływanie operatorskie $(O S$ - ang. Operator Station). Fragment takiego mini systemu rozproszonego przedstawiono na rysunku 1.

Konfigurację stacji (PS1, PS2 i OS) przeprowadza się zazwyczaj za pomocą stacji inżynierskiej (ES - ang. Engineering Station), która jest także narzędziem diagnostycznym [6]. Utworzone w stacji inżynierskiej projekty zawierające konfigurację stacji i programy sterujące przesyłane są za pośrednictwem sieci komputerowej do stacji procesowych. Podobnie przesyła się także do stacji operatorskich konfigurację obrazów graficznych wizualizujących proces [7].

Pomiędzy stacjami takiego systemu prowadzona jest komunikacja. Funkcjonowanie procesów sterowania w stacji procesowej lokalnej jest uzależnione od poprawnego uzyskania wartości niezbędnych zmiennych procesowych ze stacji odległej. Stacje systemu wymieniają dane - wartości zmiennych procesowych.

Układy dozorująco-terapeutyczne stacji systemu prowadzą diagnozowanie procesu komunikacji. Ich zadaniem jest sterowanie komunikacją $\mathrm{w}$ taki sposób, aby zapewnić bezpieczeństwo przesyłanym danym. Bezpieczeństwo przesyłanych danych można rozpatrywać $\mathrm{w}$ dwu aspektach $[1,10]$. W pierwszym $\mathrm{z}$ nich chodzi o wrażliwość na działanie zewnętrznych czynników destrukcyjnych na proces transmisji danych, a tym samym o skutki wpływu tych czynników na bezpieczeństwo prowadzonego procesu sterowania. Bezpieczeństwo transmisji może być osiągane za pomocą mechanizmów zapewniających integralność przesyłanych danych. W drugim - o zabezpieczenie transmitowanych danych przed nieupoważnionym dostępem z zewnątrz.

Pozostawanie systemu komunikacji w stanie bezpieczeństwa - czego objawem jest dostarczanie poprawnych wartości zmiennych procesowych z jednej stacji do innej $\mathrm{w}$ założonym przedziale czasu - jest, na potrzeby niniejszego opracowania, utożsamiane $\mathrm{z}$ pozostawaniem systemu komunikacji $\mathrm{W}$ stanie zdatności zadaniowej. Poprawność danych kontrolowana jest za pomocą jednokierunkowej funkcji skrótu [14] obliczanej $\mathrm{z}$ wartości przesyłanej zmiennej i dodatkowo dołączanej do transmitowanych danych. Dzięki temu uzyskuje się zachowanie integralności przesyłanych danych procesowych. W pracy proponuje się wykorzystanie jednokierunkowej funkcji skrótu do zabezpieczenia transmisji przed zmianą jej treści spowodowaną np. ingerencją intruza [10]. Przedstawiono rozwiązania wykorzystujące jeden lub więcej kanałów transmisyjnych. 


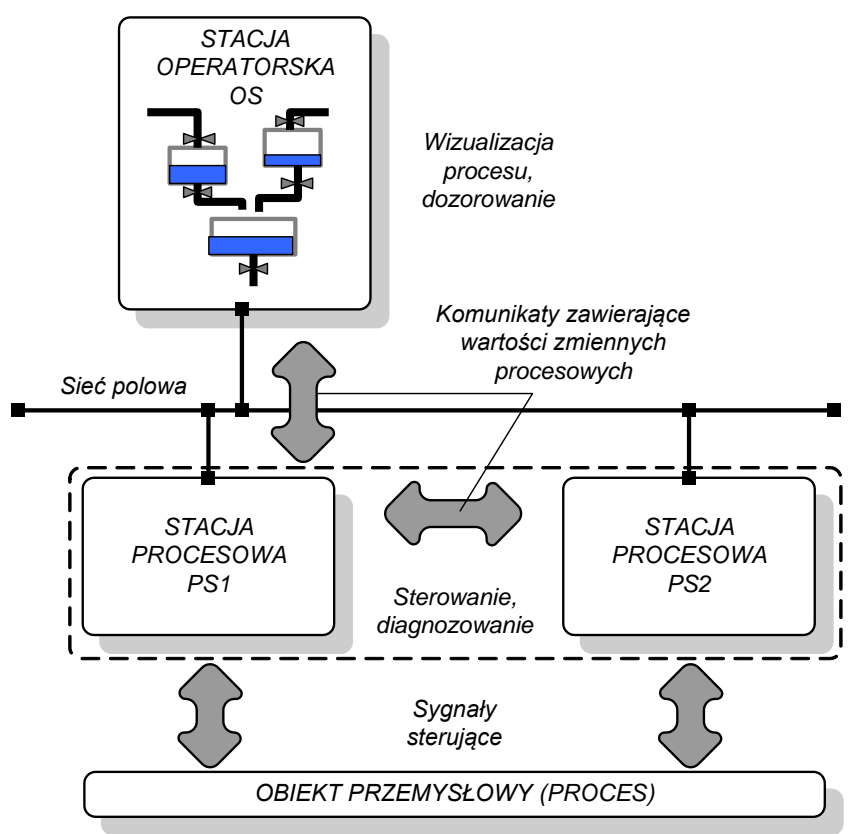

Rys. 1. Ilustracja przesyłu wartości zmiennych procesowych $w$ mini systemie rozproszonym

\section{Zdatność systemu}

Zdatność systemu transmisji danych rozpatrywana jest jako wielkość przedziałowa. Zgodnie $\mathrm{z}$ założeniami zawartymi $\mathrm{w}$ potencjałowo-efektowym podejściu do diagnozowania systemów antropotechnicznych [5] można przyjąć, iż system komunikacji uznany jest za zdatny do zrealizowania zadania użytkowego tylko wtedy, gdy potencjał dysponowany w przedziale czasu realizacji zadania jest nie mniejszy od potencjału wymaganego $\mathrm{w}$ tym przedziale. $\mathrm{W}$ rozpatrywanym przypadku oznacza to konieczność zapewnienia czasu transmisji nie dłuższego od narzuconego czasu realizacji zadania. Można to zapisać (1) następująco:

$$
\left.\begin{array}{l}
F_{P-d y s}\left(T_{t r}\right) \geq F_{P-w y m}\left(T_{z a d}\right) \\
T_{t r} \leq T_{z a d}
\end{array}\right\} \Rightarrow \varepsilon=\varepsilon^{l}
$$

gdzie:

$F_{P-d y s}$ - potencjał dysponowany;

$F_{P \text {-wym }}$ - potencjał wymagany;

$T_{t r} \quad$ - czas transmisji komunikatu;

$T_{\text {zad }}$ - przedział czasu realizacji zadania;

$\varepsilon \quad-\quad$ stan systemu transmisji;

$\varepsilon^{l} \quad-\quad$ stan zdatności systemu transmisji. 
Selected aspects of the security of the process data transmission in the distributed... Wybrane aspekty bezpieczeństwa przesyłania danych procesowych...

Bezpiecznościowy potencjał dysponowany, a dokładniej poziom potencjału dysponowanego, może być wyrażony liczbą odwzorowującą rodzaj poprawnie i bezbłędnie przesłanych składowych komunikatu (poziomy bezpiecznościowego potencjału wymaganego można określić analogicznie):

$F_{P-d y s}=1 \quad$ - dostarczenie jawnej wartości zmiennej procesowej;

$F_{P-d y s}=2$ - dostarczenie jawnej wartości zmiennej procesowej $\mathrm{z}$ dołączoną, obliczoną wartością funkcji skrótu z wartości zmiennej procesowej;

$F_{P-d y s}=3 \quad$ - dostarczenie zaszyfrowanej wartości zmiennej procesowej z dołączoną, obliczoną wartością funkcji skrótu $\mathrm{z}$ wartości zmiennej procesowej;

$F_{P-d y s}=4$ - dostarczenie zaszyfrowanej wartości zmiennej procesowej z dołączoną, obliczoną, zaszyfrowaną wartością funkcji skrótu $\mathrm{z}$ wartości zmiennej procesowej.

Drugim warunkiem zdatności (a tym samym bezpieczeństwa) systemu transmisji jest nieprzekroczenie przez czas transmisji dopuszczalnego przedziału czasu realizacji zadania (1). Czas realizacji zadania można wyrazić poprzez czas cyklu transmisji komunikatu. Transmisja jest bowiem prowadzona cyklicznie w równych odstępach czasu:

$$
T_{z a d}=T_{C}
$$

gdzie:

$$
T_{C} \text { - czas cyklu wysyłania komunikatu. }
$$

Podstawiając (2) do (1) otrzymuje się warunek (3):

$$
T_{t r} \leq T_{C}
$$

Tak więc czas transmisji komunikatu zawierającego wartość zmiennej oraz informację potrzebną do sprawdzenia integralności (wartość funkcji skrótu) przesłanych danych, a także ewentualne potwierdzenie zwrotne, powinien być nie większy niż czas cyklu wysyłania komunikatu (jest to warunek stanu zdatności). Należy zaznaczyć, że czas transmisji zawiera w sobie także czas potrzebny na przygotowanie danych do wysyłki. W dalszej części opracowania omówione są aspekty związane $\mathrm{z}$ czasem transmisji oraz $\mathrm{z}$ metodami zwiększenia rezerwy czasowej pozwalającej na np. ewentualne repetycje komunikatów.

\section{Transmisja standardowa}

Standardowa transmisja, bez dodatkowych programowych zabezpieczeń integralności komunikatu, odbywa się w sposób przedstawiony na rysunku 2. Stacja procesowa (nadawca) wysyła komunikat zawierający wartość danej do stacji procesowej odbiorcy $\left(F_{P-d y s}=1\right)$. W przypadku, gdy wymagane jest potwierdzenie otrzymania wartości - wysyłany jest zwrotnie nadesłany komunikat. Pozytywny wynik sprawdzenia zgodności wysłanego komunikatu z odebranym oraz nieprzekroczenie czasu realizacji zadania świadczy o zdatności systemu (zgodnie ze standardowo przyjętym poziomem: $F_{P \text {-wym }}=1$ ). 


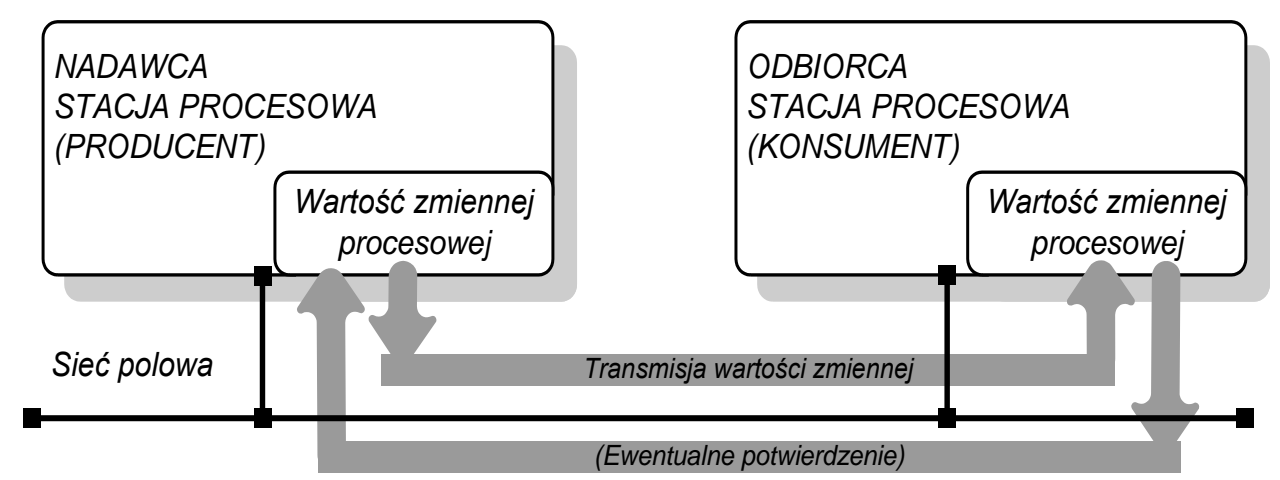

Rys. 2. Ilustracja standardowego przesyłu wartości zmiennych procesowych

$\mathrm{Na}$ rysunku 3 przedstawiono schematycznie składowe czasu transmisji dla przypadku bez potwierdzania (a) i z potwierdzaniem (b).

a)

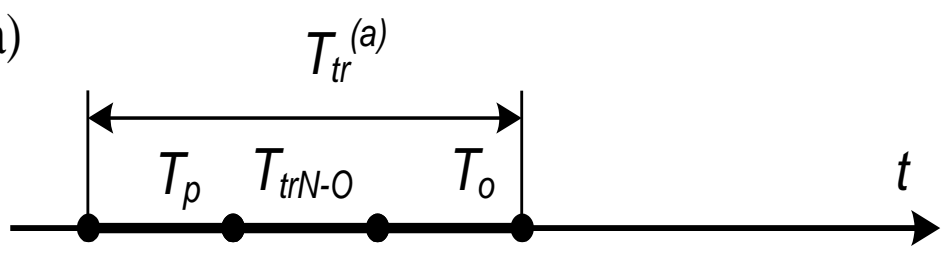

b)

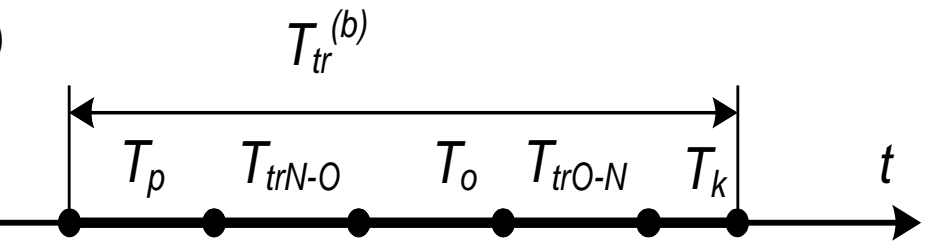

Rys. 3. Czas transmisji wartości zmiennej dla przypadku:

a) bez potwierdzania; b) z potwierdzaniem

Dla przypadku bez potwierdzania (rys. 3a) czas transmisji, który w celu zachowania bezpieczeństwa (a tym samym stanu zdatności) układu komunikacji, nie może przekroczyć czasu cyklu, wynosi (4):

$$
T_{t r}^{(a)}=T_{p}+T_{t r N-O}+T_{o}
$$

gdzie:

$T_{p} \quad$ - czas potrzebny nadawcy na przygotowanie wartości zmiennej; 
Selected aspects of the security of the process data transmission in the distributed... Wybrane aspekty bezpieczeństwa przesyłania danych procesowych...

$T_{t r N-O}$ - czas transmisji komunikatu (zawierającego wartość zmiennej) od nadajnika do odbiornika;

$T_{o} \quad$ - czas potrzebny odbiorcy na przygotowanie wartości zmiennej do przetwarzania.

W przypadku wersji z potwierdzaniem (rys. 3b) do łącznego czasu transmisji należy doliczyć okresy czasu związane ze zwrotnym przesyłem danych oraz porównaniem wartości zwróconej z wysłaną (5):

gdzie:

$$
T_{t r}^{(b)}=T_{p}+T_{t r N-O}+T_{o}+T_{t r O-N}+T_{k}
$$

$T_{\text {tro-N }}{ }^{-}$czas zwrotnej transmisji komunikatu (zawierającego wartość zmiennej) od odbiorcy do nadawcy;

$T_{k}$ - czas niezbędny na dokonanie komparacji wartości zwróconej z wartością wysłaną.

Przy ustalaniu czasu cyklu, zgodnie z którym wysyłane są cykliczne komunikaty, należy pamiętać o zapewnieniu odpowiedniej rezerwy czasowej $\Delta t$ :

$$
\Delta t=T_{c}-T_{t r} \geq 0
$$

tj. minimalnie:

$$
T_{c}=T_{t r}
$$

W przypadku zastosowania obliczenia jednokierunkowej funkcji skrótu dla zwiększenia bezpieczeństwa przesyłanych danych należy stosować się do zaleceń z punktu 4 .

\section{Zapewnienie integralności przesyłanych danych}

W celu zapewnienia większego bezpieczeństwa w omawianym układzie można zastosować procedurę dołączenia do wartości zmiennej procesowej, dodatkowej wartości obliczonej funkcji skrótu. Tego typu „zabieg” powoduje, że potencjał dysponowany, uzyskany w wyniku prawidłowego przesyłu komunikatu zwiększa się (zgodnie z p. 2) do wartości $F_{P-d y s}=2$.

W tym wariancie przesyłu nadawca (rys. 4) oblicza wartość funkcji skrótu z wartości przesyłanej zmiennej. Konkatenowane wartości są przesyłane wspólnym komunikatem do odbiorcy (konsumenta). Odbiorca wyodrębnia $\mathrm{z}$ wiadomości wartość zmiennej oraz wartość funkcji skrótu. Ponownie oblicza skrót i porównuje go $\mathrm{z}$ wartością odebraną. Jeśli w wyniku porównania uzyskuje się potwierdzenie nienaruszenia wartości zmiennej procesowej oraz nie nastąpiło przekroczenie założonego czasu cyklu (czas transmisji $T_{t r}{ }^{(c)}$ ), uznaje się system transmisji za zdatny mimo zwiększonego poziomu potencjału wymaganego $\left(F_{p \text {-wym-max }}=2\right)$. 


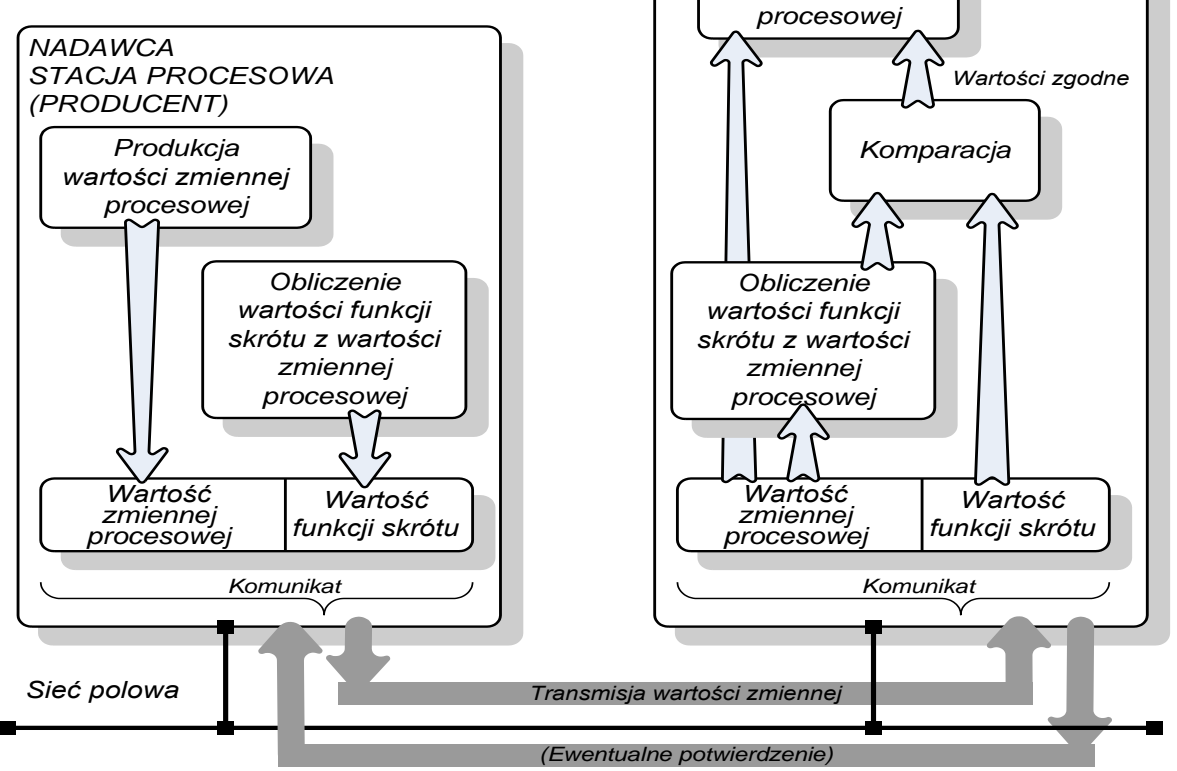

Rys. 4. Ilustracja przesyłu wartości zmiennej procesowej z dołączoną wartościa funkcji skrótu

Czasy: przygotowania, transmisji i odbioru zwiększają się odpowiednio o czas niezbędny do przetwarzania wartości funkcji skrótu (rys. 5a - bez potwierdzania):

- czas przygotowania przez nadawcę wartości do wysłania:

gdzie:

$$
T_{p}=T_{p d}+T_{p s}
$$

$T_{p d}$ - czas potrzebny na przygotowanie wartości zmiennej;

$T_{p s}$ - czas potrzebny na przygotowanie wartości funkcji skrótu $\mathrm{z}$ wartości zmiennej

- czas transmisji danych od nadawcy do odbiorcy:

gdzie:

$$
T_{t r N-O}=T_{t r d}+T_{t r s}
$$

$T_{\text {trd }}$ - czas potrzebny na przesył wartości zmiennej;

$T_{t r s}$ - czas potrzebny na produkcję wartości funkcji skrótu z wartości zmiennej 
Selected aspects of the security of the process data transmission in the distributed... Wybrane aspekty bezpieczeństwa przesyłania danych procesowych...

- czas potrzebny odbiorcy na przygotowanie wartości do dalszego przetwarzania:

gdzie:

$$
T_{o}=T_{o d}+T_{o s}+T_{o k s}
$$

$T_{o d}$ - czas potrzebny na odbiór przez odbiorcę wartości zmiennej;

$T_{o s}$ - czas potrzebny na odbiór wartości funkcji skrótu $\mathrm{z}$ wartości zmiennej oraz obliczenie własnej wartości funkcji skrótu;

$T_{o k s}$ - czas potrzebny odbiorcy na porównanie nadesłanej wartości skrótu i obliczonej.

Podstawiając (8-10) do (4) otrzymuje się składniki łącznego czasu transmisji $\mathrm{w}$ wariancie z obliczaniem wartości funkcji skrótu bez potwierdzania (11):

$$
T_{t r}^{(c)}=T_{p}+T_{t r N-O}+T_{o}=T_{p d}+T_{p s}+T_{t r d}+T_{t r s}+T_{o d}+T_{o s}+T_{o k s}
$$

a)

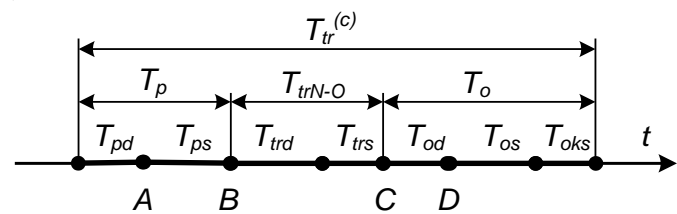

b)

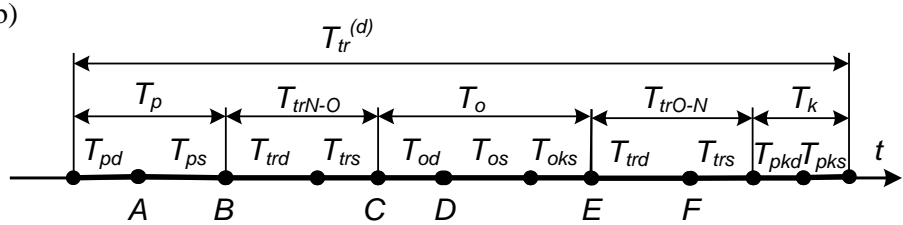

Rys. 5. Czas transmisji wartości zmiennej z obliczona wartościa funkcji skrótu dla przypadku: a) bez potwierdzania; b) z potwierdzaniem

W przypadku wariantu z potwierdzaniem odbioru (tzw. transmisja połączeniowa) do sumy czasów wg (5) dochodzą jeszcze dodatkowe składniki (12) tj.:

$$
\begin{gathered}
T_{t r}^{(d)}=T_{p}+T_{t r N-O}+T_{o}= \\
=T_{p d}+T_{p s}+T_{t r d}+T_{t r s}+T_{o d}+T_{o s}+T_{o k s}+T_{t r d}+T_{t r s}+T_{o d}+T_{p k d}+T_{p k s}= \\
=T_{p d}+T_{p s}+2 T_{t r d}+2 T_{t r s}+T_{o d}+T_{o s}+T_{o k s}+T_{o d}+T_{p k d}+T_{p k s}
\end{gathered}
$$

gdzie:

$T_{t r d}$ - czas dodatkowej zwrotnej transmisji wartości zmiennej;

$T_{t r s}$ - czas dodatkowej zwrotnej transmisji wartości skrótu;

$T_{p k d}$ - czas niezbędny na dokonanie komparacji zwróconej wartości zmiennej z wartością wysłaną;

$T_{p k s}$ - czas niezbędny na dokonanie komparacji zwróconej wartości skrótu z wartością wysłaną. 
Dodatkowe wartości przedziałów czasu w przypadku zdatności systemu transmisji nie mogą powodować niespełnienia warunku (3).

W praktyce można to osiągnąć dwoma sposobami:

1) złagodzeniem warunku czasowego, tj. zwiększeniem czasu cyklu, co który będzie generowany komunikat $\mathrm{z}$ wartościami lub

2) zastosowaniem rozdzielenia przesyłu wartości zmiennej procesowej i wartości skrótu z zastosowaniem odrębnego kanału przesyłu dla każdej z nich.

Obydwa sposoby zwiększają dostępną rezerwę czasową (por. (6)).

Zgodnie $\mathrm{z}$ ww. 2. sposobem zwiększenia rezerwy czasowej niezbędnej do prawidłowego i bezpiecznego działania systemu transmisji jest podział przesyłu na dwa komunikaty, każdy niosący informację o jednej z dwu wartości - odrębny dla wartości zmiennej, odrębny dla wartości funkcji skrótu - transmitowanych oddzielnymi kanałami transmisyjnymi. Dzięki takiej organizacji procesu przesyłu uzyskuje się zmniejszenie czasu przesyłu całości informacji.

W przypadku zastosowania ww. sposobu transmisja wartości zmiennej może rozpocząć się nawet wówczas, gdy wartość funkcji skrótu nie jest jeszcze gotowa do wysyłki (rys. 5, punkt $A$ ). Otrzymuje się oszczędność czasu wyznaczoną odcinkiem $A B$. Zysk czasowy można uzyskać także w procesie odbioru i przetwarzania. Przetwarzanie wartości funkcji skrótu także może rozpocząć się wcześniej niż w przypadku zachowania szeregowej budowy systemu transmisji (rys. 5, punkt $C$ ). Oszczędność czasu wyznacza odcinek $C D$. Podobnie dla wariantu $\mathrm{z}$ potwierdzaniem - zwiększenie rezerwy czasowej (odcinek $E F$ ) uzyskuje się dzięki wcześniejszemu zwrotnemu przesyłowi wartości funkcji skrótu (rys. 5b, punkt $E$ ).

\section{Badania czasu wykonania bloku zapewniającego integralność przesylanych danych}

Dla porównania i zobrazowania skali zwiększenia czasu transmisji wartości zmiennej przy zastosowaniu bloku obliczającego wartość funkcji skrótu wg algorytmu SHA-256 [9], wykonanego w języku ST [11], podano wyniki dla emulatora sterownika przemysłowego uruchomionego w wirtualnym środowisku. Systemowi wirtualnemu oddano do dyspozycji 2GB pamięci RAM, wykorzystano komputer przenośny z procesorem IntelCore2 Duo 2,0 GHz. Czas cyklu zadania stacji procesowej realizującego obliczenia wartości funkcji skrótu ustalono na $5 \mathrm{~ms}$ [2]. Na rysunkach 6 i 7 przedstawiono wyniki serii 7 prób pomiaru czasu obliczania wartości funkcji skrótu z wartości wejściowej 20 i 200. Uzyskane wartości czasów w obydwu przypadkach wahają się w granicach od 38 do 68 ms. 
Selected aspects of the security of the process data transmission in the distributed... Wybrane aspekty bezpieczeństwa przesyłania danych procesowych...

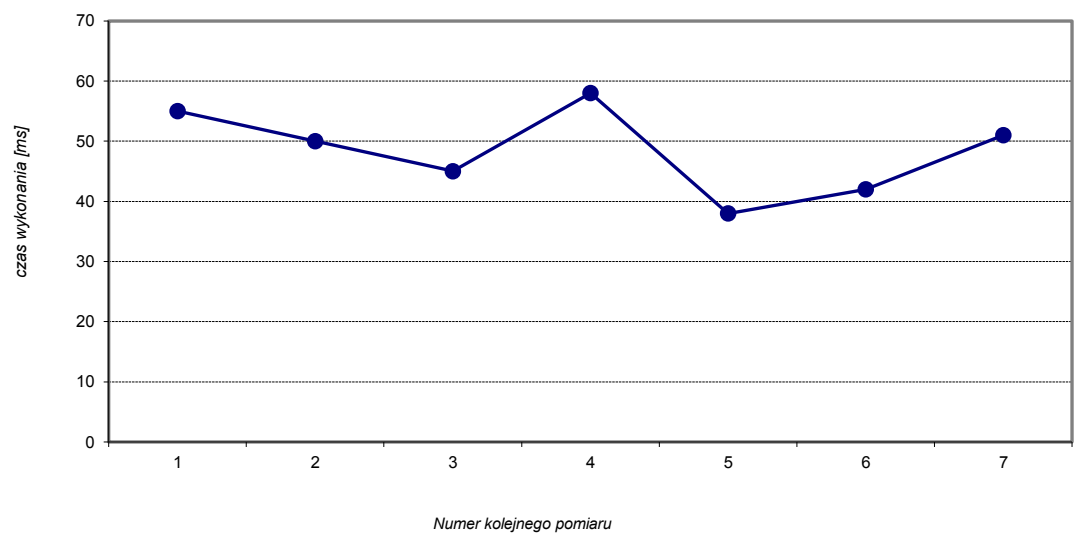

Rys. 6. Czas wykonania bloku obliczenia wartości funkcji skrótu SHA-256 dla czasu cyklu zadania 5 ms $i$ wartości wejściowej równej 20

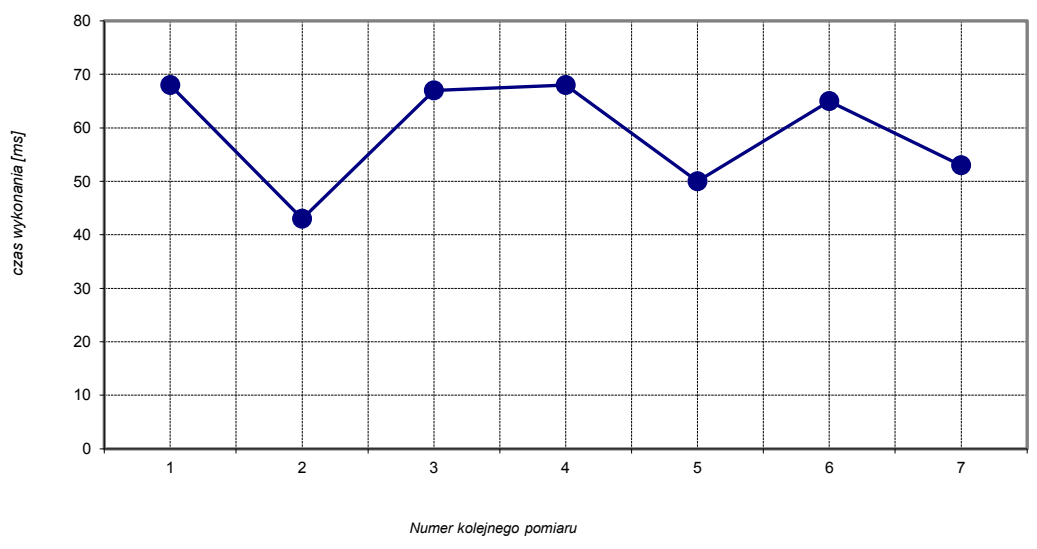

Rys. 7. Czas wykonania bloku obliczenia wartości funkcji skrótu SHA-256 dla czasu cyklu zadania 5 ms i wartości wejściowej równej 200

Uzyskane wartości czasów działania bloku obliczania wartości funkcji skrótu dają pełniejszy obraz dopiero po porównaniu ich z założonym czasem cyklu, z którym wysyłany jest komunikat. Można zauważyć, że dla założonego czasu cyklu wymiany komunikatów 200 ms, wartości te stanowią odpowiednio od 19\% do 34\% całego czasu dostępnego dla jednej wymiany danych. Dla tak dobranych czasów nie stanowi to problemu. W bardziej złożonych zastosowaniach, gdzie wartość funkcji skrótu obliczana jest wielokrotnie i dodatkowo zastosowane są inne mechanizmy bezpieczeństwa np. szyfrowanie, dobór zbyt małego czasu zadania $T_{z a d}$ może prowadzić do niezdatności systemu transmisji. 


\section{Podsumowanie}

$\mathrm{Na}$ podstawie przedstawionych $\mathrm{w}$ opracowaniu rozważań można sformułować kilka wniosków dotyczących komunikacji z zastosowaniem mechanizmów bezpieczeństwa:

1) Zastosowanie dołączania wartości funkcji skrótu, obliczanej na podstawie wartości przesyłanej zmiennej procesowej, pozwala na zachowanie integralności komunikatu i przeciwdziała ewentualnym atakom na integralność.

2) Wykorzystanie ww. mechanizmu pozwala na podniesienie poziomu dysponowanego potencjału bezpieczeństwa dla systemu komunikacji.

3) Wraz z wielokrotnym zastosowaniem funkcji skrótu rośnie także czas potrzebny na uzyskanie przez odbiorcę wartości zmiennej procesowej. Fakt ten należy uwzględnić przy projektowaniu wymian cyklicznych i odpowiednio wydłużyć czas cyklu, aby niezdatność systemu nie była powodowana przekroczeniem wymaganego czasu transmisji.

4) Czas potrzebny na obliczenie wartości funkcji skrótu jest relatywnie mały w stosunku do ewentualnych repetycji nieudanych, niezdatnych komunikatów (kilkadziesiąt milisekund obliczeń w stosunku do np. kilku sekund ustawianego parametru timeout).

\section{Literatura}

[1] Anderson Ross J.: Security Engineering: A Guide to Building Dependable Distributed Systems, 2nd Edition, Willey, Hoboken 2008.

[2] Bednarek M.: Wizualizacja procesów. Laboratorium, Oficyna Wydawnicza Politechniki Rzeszowskiej, Rzeszów 2004.

[3] Bednarek M., Dąbrowski T.: Koncepcja zabezpieczenia transmisji danych w mobilnym systemie diagnostycznym, Journal of KONBiN, z.2(26)/2013, s. 61-70.

[4] Bednarek M., Dąbrowski T., Wiśnios M.: Koncepcja zabezpieczenia transmisji pomiędzy stacjami diagnostycznymi, Pomiary Automatyka Kontrola, Wydawnictwo PAK, nr 9/2014, 749-752.

[5] Dąbrowski T.: Diagnozowanie systemów antropotechnicznych w ujęciu potencjałowo-efektowym, Rozpr. hab., Wyd. Wojskowej Akademii Technicznej, Warszawa 2001.

[6] Dokumentacja techniczna AC800F. Engineering Manual. IEC 61131-3 Programming.

[7] Dokumentacja elektroniczna Control Builder F. Freelance Getting Started, 2010.

[8] Ferguson N., Schneier B., Kohno T.: Cryptography Engineering: Design Principles and Practical Applications, Willey, 2010.

[9] Gilbert Henri, Handschuh Helena: Security Analysis of SHA-256 and Sisters, Selected Areas in Cryptography, Springer 2003, s. 175-193.

[10] Liderman K.: Bezpieczeństwo informacyjne. Wydawnictwo PWN, Warszawa 2012.

[11] IEC 61131-3:2013. Programmable controllers - Part 3: Programming languages. 
Selected aspects of the security of the process data transmission in the distributed... Wybrane aspekty bezpieczeństwa przesytania danych procesowych...

[12] Stallings W.: Kryptografia i bezpieczeństwo sieci komputerowych. Matematyka szyfrów i techniki kryptologii, Helion, 2011.

[13] Stamp M.: Information security, J. Wiley \& Sons, Hoboken, 2006.

[14] Stinson R. Douglas: Kryptografia. W teorii i praktyce, WNT, Warszawa 2005.

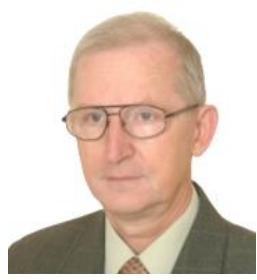

dr hab. inz Tadeusz Dabrowski jest profesorem nadzwyczajnym na Wydziale Elektroniki Wojskowej Akademii Technicznej. Jego zainteresowania naukowe koncentruja sie $w$ obszarze teorii eksploatacji - głównie na diagnostyce technicznej. Do ważniejszych zagadnień, którymi się zajmuje należa: diagnostyka obiektów technicznych $i$ systemów antropotechnicznych (głównie $w$ aspekcie użytkowym i bezpiecznościowym); optymalizacja procesów diagnostyczno-obshugowych; komputerowe wspomaganie procesu diagnostyczno-obshugowego; niezawodność eksploatacyjna obiektów. (Udziat: 30\%).

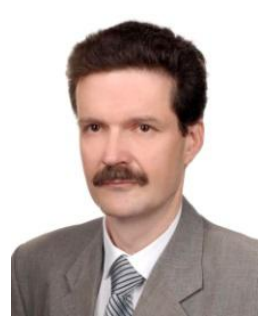

dr inz. Marcin Bednarek pracuje na stanowisku adiunkta w Katedrze Informatyki i Automatyki Wydziatu Elektrotechniki i Informatyki Politechniki Rzeszowskiej. Główny obszar jego zainteresowań naukowych to: diagnostyka systemów antropotechnicznych, komunikacja $w$ rozproszonych systemach sterowania, niezawodność $i$ bezpieczeństwo systemów. Jest autorem/wspótautorem ponad 100 publikacji. (Udziat: 50\%).

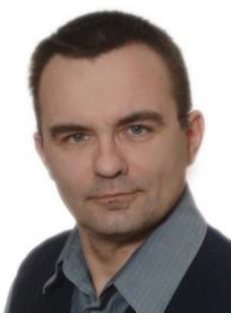

mgr inz. Tomasz. Wawer jest absolwentem Politechniki Warszawskiej, Wydziatu Mechatroniki. Jest specjalista w zakresie projektowania i implementacji informatycznych projektów infrastruktury serwerowej i macierzowej. Od 5 lat rozwija własna firme konsultingu IT. Prywatnie jest pasjonatem technik krótkofalarskich, znak SQ5RIX. (Udziat: 20\%). 